\title{
E-Learning during COVID-19 Pandemic: Turning a Crisis into Opportunity
}

Amjad Bani Hani ( $\square$ amjadbh@yahoo.com)

University of Jordan

Yazan Hijazein

University of Jordan

Hiba Hadadin

University of Jordan

Alma Jarkas

University of Jordan

Zahraa Al-Tamimi

University of Jordan

Marzouq Amarin

University of Jordan

Amjad Shatarat

University of Jordan

Mahmoud Abu Abeeleh

University of Jordan

Raed Al-Taher

University of Jordan

Research Article

Keywords: E-learning, school of medicine, medical education, COVID-19, pandemic

Posted Date: September 3rd, 2021

DOI: https://doi.org/10.21203/rs.3.rs-112908/v2

License: (c) (1) This work is licensed under a Creative Commons Attribution 4.0 International License. Read Full License 


\section{Abstract}

Objectives: To assess the medical students' satisfaction and knowledge attainment through distant learning during the COVID-19 pandemic.

Methods: This is a cross-sectional, self-reported, questionnaire-based study that was conducted at the School of Medicine at the University of Jordan in April 2020. The targeted population was the students at the school of medicine. An online questionnaire was created using Google Forms. Satisfaction and knowledge attainment among students were assessed using independent-samples t-test.

Results: A total of 1000 medical students completed the survey, 506 (50.6\%) basic science students and 494 (49.4\%) were clinical science students. 655 $(65.5 \%)$ of all students were either satisfied, or neutral with e-learning and $63.6 \%$ of basic science students and $59.5 \%$ of clinical students stated that they gained and understood knowledge the same or better than they did before initiation of exclusive e-learning. Satisfaction and knowledge gain were significantly affected by student preparedness $(p<0.000)$, teacher performance $(p<0.000)$, and website accessibility $(p<0.000)$.

Conclusion: Transition from traditional in-class teaching to distant learning, whether full or blended, is an inevitable step., In our sample, students were generally satisfied with e-learning and the knowledge attained using it. There was a significant relation between satisfaction and attainment and preparedness of students, teachers, and the medical school.

\section{Introduction}

On March 11, 2020, the Director-General of the World Health Organization publicly declared COVID-19 a pandemic. Countries worldwide put in place social distancing and stay-at-home measures to "flatten the curve" and slow the spread of COVID-19. The Hashemite Kingdom of Jordan was one such country. As such, universities in Jordan and many countries across the world had to cancel or suspend their campus activities and rely exclusively on e-learning to continue student education.(1)

The term e-learning refers to learning by using electronic technology to access educational materials and curriculum outside the classroom walls. E-learning has been introduced to almost all specialties and levels of education. It has been estimated that over the next couple of years, e-learning will grow 15 folds, to account for $30 \%$ of all educational provision throughout the globe.(2) The World Federation for Medical Education global guidelines endorse technology as a key component of best-practice medical education.(3)

The delivery of e-learning comprises easy access to information, updating, distribution, and standardization of content.(4) It gives the ability to revise and control content simply and quickly to meet their learning objects. Furthermore, it helps in distributing the content to many users simultaneously, anytime, and anywhere.(5)

The COVID-19 pandemic resulted in a challenge and an opportunity to use and assess E-learning in higher education. This study aims to illustrate students' attitudes and the impact of transitioning towards e-learning methods in the faculty of medicine at the University of Jordan (UJ).

\section{Methodology}

This is a cross-sectional, self-reported, questionnaire-based study that was conducted at the School of Medicine at the University of Jordan in April 2020. The targeted population was the students at the school of medicine throughout the basic and clinical years of study. An online questionnaire was created using Google Forms $\odot$. Medical students from year 1 to year 6 (the final year of medical school at the University of Jordan) participated in this survey. Basic science students (BSS) comprise year one to the third year, while clinical students (CS) comprise year four to six. The questionnaire was distributed to students in basic and clinical medical years through University of Jordan e-learning platform and Facebook and WhatsApp students' groups. The questionnaire included a written consent on its first page. The questionnaire is composed of multiple sections. The first section inquiries about the gender, the level of study and current grade point average (GPA). The $2^{\text {nd }}$ section assesses students' thoughts about the preparedness of his/her school and their own preparedness for e-learning use. The $3^{\text {rd }}$ section enquiries about the devices that the student uses in e-learning. The $4^{\text {th }}$ section enquires about the tools used in e-learning, duration, and number of sessions and rating of lecturers' performance in e-learning. The $5^{\text {th }}$ section compares classical teaching with e-learning, and the final section probes students' mental health in the acute setting of the COVID-19 pandemic manifested as depression or anxiety.

Data were analysed via SPSS version 25. One-way ANOVA and univariate analysis t-test with post hoc LSD, an independent-samples t-test were performed to find the relationship between different students' characteristics, surrounding circumstances, and e-learning tools available with the dependent variables in terms of school preparedness, students' preparedness, the efficacy of e-learning process, and students' mental health status.

The study was approved by the Institutional Review Board of the Medical School of the University of Jordan. An informed consent was obtained by each student before participation. All methods were performed in accordance with the relevant guidelines and regulations.

The datasets generated during and/or analysed during the current study are available from the corresponding author on reasonable request.

\section{Results}


A total of 1000 medical students participated in the survey. Of all medical students participating in this study, 506 medical students are from the fundamental science years (50.4\%), and 494 medical students are from the clinical years (49.6\%). Five hundred fifty-three students declared their GPA. Table 1 describes the GPA distribution of the students.

Table 2 shows that there is a statistically significant difference in student satisfaction from e-learning between basic science students (BSS) and clinical students (CS). $156(30.8 \%)$ of BSS was unsatisfied compared to $189(38.3 \%)$ of CS $(p<0.012)$. Satisfaction was also affected by student preparedness, with $222(42.9 \%)$ of non-experienced students being unsatisfied, while only $123(25.5 \%)$ of experienced students expressed the same ( $<<0.000)$. Teacher performance also affected student satisfaction, with only 10 (4.8\%) of students who rated a teacher's performance as unsatisfying, while 58 (12.2\%) and 123 $(39.3 \%)$ of students satisfied with their e-learning experience-rated teacher performance neutral and satisfying, respectively $(p<0.000)$.

Furthermore, around $50 \%$ of all students recognize the university's E-learning website available for easy access. There was no statistically significant difference in satisfaction level when compared to students' scores on Becks' Anxiety Inventory.

Table 3 assesses clinical knowledge gained throughout the use of e-learning during the COVID-19 lockdown. Of all medical students at the University of Jordan, $63.6 \%$ of BSS and $59.5 \%$ of CS stated that they gained and understood knowledge the same or better than before initiation of exclusive e-learning. Factors affecting knowledge gained were teacher e-learning performance, students experience in using eLearning, and the university's e-learning website available for easy access $(\mathrm{p}<0.000)$. Of all medical students that took the survey that rated their teacher's performance as dissatisfying, 18 ( $8.6 \%)$ stated they gained knowledge better than before the lockdown. In comparison, $98(20.5 \%)$ of the neutral teacher's performance and 121 (38.7\%) of the satisfying teacher performance groups said the same $(p<0.000)$.

The most popular devices used to connect to the internet were mobile phones and laptops, with around 1000 students saying they always used these devices, as illustrated in figure 1. The least popular tools were the tablet and the desktop computer. The desktop computer was the least used out of all, with around 1000 students saying they never use it for medical education. We also asked students about their most-used platforms for e-learning, as shown in table 5. Video conference platforms such as Zoom and Skype were used by $60 \%$ of students, and YouTube came second, with $56.7 \%$. Moodle was used by $48.5 \%$ of students, while Microsoft Teams was the least used platform, with only $24 \%$ of students utilizing it.

Overall, $763(76.3 \%)$ of all the students believe that the electronic devices did not cause any financial burden, whereas 144 (14.4\%) believe electronic devices cause some, and 92 (9.2\%) believe they did cause a financial burden. The internet connection did not cause any financial in 666 (66.6\%), whereas 212 (21.2\%) reported it causes some, and 121 (12.1\%) stated it did cause a financial burden.

Among basic science students, 229 (45.2\%) believed that the school's e-learning infrastructure was well-established and started a long time ago. In comparison, only $83(16.8 \%)$ of clinical students had the same opinion. $190(37.6 \%)$ of basic science students and 202 (40.8\%) of clinical students believed elearning was only applied recently before this crisis and is still evolving. Among BSS and CS students, 71 (14\%) and 192 (38.9\%) reported that e-learning was only used during this crisis, respectively.

When students were asked to rate their satisfaction with the recent transition to e-learning education during the COVID-19 outbreak, 244 (48.2\%) of BSS and 224 (45.4\%) of CS were neutral, while $108(21.4 \%)$ of BSS and $83(16.8 \%)$ of CS were satisfied.

\section{Discussion}

The introduction of the computer and the internet has forced both teachers and students to integrate the available technology in medical education. Some changes were passive, due to development that affected the world of communication and the birth of the digital native generation, which cannot separate advanced technology from their daily lives. Operational changes were introduced to the field of healthcare while also affecting the dynamic economics of healthcare education. Since the emergence of the COVID-19 pandemic, all areas of distant communication and learning were accelerated, this change being permanent in many ways. ${ }^{14}$

Although it may be feasible for e-learning to replace classroom setting education in some fields entirely, medical education is heavily reliant on student-patient interaction, bed-side learning, and in-person attendance of surgical procedures and teaching rounds. This could pose a challenge to the incorporation of elearning into medical teaching.(6) As such, e-learning use is highly variable among medical schools and appears to be more common in basic science courses than in clinical clerkships.(4)

\section{Student Satisfaction}

Teachers' performance, students' experience in using e-learning platforms and websites, and accessibility to websites have shown to have a significant impact on student satisfaction in this study as shown in table 4. Students' satisfaction is higher when their teachers' performance was satisfying. Teacher performance in e-learning is influenced by multiple factors, including time-consuming production of e-learning materials that may interfere with physicians' busy schedules, the availability of technical support during the implementation of e-learning and the wide range of strategies to facilitate e-learning.(7,8) The variability in teacher performance can be addressed by designating permanent staff members exclusively in charge of e-learning which can assist teachers by providing details of the programs used to create e-learning content.(8) In addition to providing the appropriate infrastructure for teachers, motivational incentives may be encouraging. $(8,9)$

Students who found the e-learning website not easily accessible were more likely to be unsatisfied with the online educational process in our study. Student satisfaction was thoroughly studied, five components were set to be the pillars of online teaching which are effectiveness, accessibility, cost-effectiveness, students' satisfaction and faculty satisfaction.(10) 
To examine the effect of anxiety associated with the COVID-19 pandemic on the teaching process, we asked the students to respond to becks anxiety scale. It showed no effect on their level of satisfaction.

\section{Knowledge attainment}

More than half of the students that participated in this study stated they gained the same or even better knowledge than what they did before the lockdown. Teachers' performance and students' experience and accessibility to websites have all affected knowledge attainment.

There does not seem to be a consensus in the literature when comparing e-learning and traditional learning. In a systemic review of 50 studies used to test knowledge gains, 12 of them found significantly higher gains in the online e-learning intervention groups than traditional learning. In contrast, 27 did not detect significant differences or mixed results were found.(11) Another study revealed that undergraduate students preferred face-to-face learning over the elearning teaching method. However, all students agreed that e-learning was good at teaching basic knowledge that required higher levels of thinking.(12)

A study about e-learning in palliative care showed that $96 \%$ of students used e-learning as a preparation tool for their exams.(13) Another survey for evaluating the effectiveness of an online teaching module in the pediatric department showed that e-learning is effective at increasing environmental health knowledge of clinical and non-clinical professionals, assessed by a pre-test and a post-test for the clinical expertise acquired from the online modules. (14) Others have shown that educational technologies for respiratory care have an important role and that online learning for baccalaureate and higher degrees in respiratory care is promising. However, it is not easier than traditional learning methods, and it is showed to be more expensive.

A study about Video-Based Learning showed that this tool's effectiveness is augmented by the teachers' consideration to management and maximizing students' engagement.(15) This suggests that when dealing with large cohorts that teach students from many courses, the development of more specific elearning materials is required for engagement levels to be maintained. This could take the form of more targeted and specialized cases and quizzes that are more directed and relevant to sub-groups of students.

Adding e-learning resources and utilizing technology to conventional Anatomy and Physiology were vital in mediating engagement and facilitating deep learning of fundamental concepts, adjusting these materials into career-specific teaching resources (how a particular organ system relates directly to their future profession) will aid learners to succeed in their studies and professions.(16)

It is worth mentioning that delivering video lectures on campus does not have the benefit of flexibility and accessibility which are major features of e-lectures. (17) Another study showed that students described a lack of control, feeling like passive recipients of e-learning, and the feeling of being lost.(18)

It is important to emphasize the role of the teacher or mentor in fostering the educational process. The teacher has a major role in explaining the content and highlighting concepts to deepen knowledge. This tends to improve knowledge gain and makes students more confident regarding the usefulness of e-learning. (17)

\section{Mobile use in medical education}

Electronic devices constitute of mobile phones, tablets, laptops, and desktops. We found that the most used electronic device for e-learning is mobile phones, followed by laptops.

Other studies have also shown the popularity of mobile device usage among students. $(19,20)$ In particular, the last decade has seen widespread access to mobile internet devices (MIDs), which in turn have expanded educational opportunities outside the classroom setting. Learners with a suitable MID and a link to the world wide web have ready access to a wide range of multimedia learning resources, collectively known as mobile learning (mLearning).(21) The perceived and actual usefulness of students using mobile devices is thus context-dependent and subject to mixed messages.(22,23) The evidence-base in health professions education must move beyond mobile device technicalities to explore how it supports learning. $(19,22)$ Students believe that mobile usage saves time, making patients' care more efficient and much easier.(19,24,25) A recurrent theme was that students were reluctant to use mobile devices in front of patients to avoid being seen as unprofessional and in front of the staff to avoid misinterpreting the reason for device usage.(19,26-29)

\section{Just in time leaming}

Mobile devices can be an efficient tool of learning whereby the device promoted just-in-time learning in the clinical context, repetition of learning, supplementing rather than replacing learning and making use of wasted time so that learning can be done without setback. $(30,31)$ Mobile phone use is the simplest way for students to access information quickly during their clinical placements. It may be beneficial to include mobile phone use in medical education in an official manner and to provide students with instruction on professionalism and communication skills. Thus, maintain a professional image in balance with learning and other duties as future healthcare professional.(32)

\section{Financial burden}

Jordan is an upper middle-income country that is under substantial national debt, the gross national income precipitate is estimated at around 4300 US\$ and the National Debt soaring around $95 \%$ from gross domestic product, the poverty rate is about $15 \% .(33,34)$ Saying so, our study showed that $9 \%$ stated that electronic devices cause students' financial burden and $12 \%$ stated that internet connection did cause them financial burden. This is not high when looking at the country's economic status, yet it represents a considerable obstacle when shifting toward e-learning, this was clear in other studies.(35)

\section{Limitations}


This cross-sectional survey is self-reported, which may cause several limitations and introduce bias. Due to the anonymity of the survey, comparing respondents with non-respondents is not possible. Students living in remote areas may have a low response rate due to the socioeconomic status and difficulties in connecting to the network. Besides that, the survey is somehow long for the respondents, creating random answers from the students as they lose engagement after spending too much time. Besides, no identification verification is used, which may lead to inaccuracy as the web-based survey can be filled multiple times, be filled by another person like a family member or a friend and be filled by non-medical students who are out of the scope of our study.

\section{Conclusion}

Transition from traditional in-class teaching to distant learning, whether full or blended, is an inevitable step., In our sample, students were generally satisfied with e-learning and the knowledge attained using it. There was a significant relation between satisfaction and attainment and preparedness of students, teachers, and the medical school.

\section{Declarations}

\section{Conflict of interest statement. None.}

Role of funding. This research received no specific grant from any funding agency in the public, commercial, or not-for-profit sectors.

\section{Authors' contributions}

Conception of the idea: A.B-H., R.A-T., H.H., and Y.H. Collection of data: A.B-H., H.H., Y.H. Data analysis and interpretation: A.B-H., R.A-T., M.A., A.S., M.A-A. Literature review: all authors. Drafting the manuscript: A.B-H., Y.H., H.H., A.J. Critical review and final approval: all authors. Accountability: all authors.

\section{References}

1. Newman NA, Lattouf OM. Coalition for medical education-A call to action: A proposition to adapt clinical medical education to meet the needs of students and other healthcare learners during COVID-19. J Card Surg. 2020;1-2.

2. Law GC, Apfelbacher C, Posadzki PP, Kemp S, Tudor Car L. Choice of outcomes and measurement instruments in randomised trials on eLearning in medical education: A systematic mapping review protocol. Syst Rev. 2018;7(1):1-5.

3. Hays R. Book: WFME Global Standards for Basic Medical Education - the 2012 Revision. Reference book available from WFME website: http://www.wfme.org/news/general-news/263-standards-for-basic-medical-education-the-2012-revision [Internet]. 2012 [cited 2020 Nov 13 ]. undefinedundefined. Available from: https://www.academia.edu/29947082/Book_WFME_Global_Standards_for_Basic_Medical_Education_the_2012_Revision._Reference_book_available_from_WF news_263-standards-for-basic-medical-education-the-2012-revision

4. Ruiz JG, Mintzer MJ, Leipzig RM. The impact of e-learning in medical education. Vol. 81, Academic Medicine. Lippincott Williams and Wilkins; 2006. p. 207-12.

5. Suresh M, Vishnu Priya V, Gayathri R. Effect of e-learning on academic performance of undergraduate students [Internet]. Vol. 10, Drug Invention Today |. 2018 Aug [cited 2020 Sep 2]. Available from: http://www.

6. Khasawneh R, Simonsen K, Snowden J, Higgins J, Beck G. The effectiveness of e-learning in pediatric medical student education. Med Educ Online [Internet]. 2016 [cited 2020 Apr 4];21(1). Available from: http://www.tandfonline.com/action/journallnformation? journalCode=zmeo20http://dx.doi.org/10.3402/meo.v21.29516

7. Davids MR, Chikte UME, Halperin ML. An efficient approach to improve the usability of e-learning resources: The role of heuristic evaluation. Am J Physiol - Adv Physiol Educ. 2013;37(3):242-8.

8. Back DA, Behringer F, Harms T, Plener J, Sostmann K, Peters H. Survey of e-learning implementation and faculty support strategies in a cluster of midEuropean medical schools. BMC Med Educ. 2015 Dec 1;15(1).

9. Choules AP. The use of elearning in medical education: A review of the current situation. Postgrad Med J. 2007;83(978):212-6.

10. Violante MG, Vezzetti E. Virtual interactive E-learning application: An evaluation of the student satisfaction. Comput Appl Eng Educ. 2015;23(1):72-91.

11. George PP, Papachristou N, Belisario JM, Wang W, Wark PA, Cotic Z, et al. Online eLearning for undergraduates in health professions: A systematic review of the impact on knowledge, skills, attitudes and satisfaction. J Glob Health. 2014;4(1).

12. Morton CE, Saleh SN, Smith SF, Hemani A, Ameen A, Bennie TD, et al. Blended learning: How can we optimise undergraduate student engagement? BMC Med Educ [Internet]. 2016 Aug 4 [cited 2020 Apr 17];16(1):1-8. Available from: http://dx.doi.org/10.1186/s12909-016-0716-z

13. Schulz-Quach C, Wenzel-Meyburg U, Fetz K. Can elearning be used to teach palliative care? - Medical students' acceptance, knowledge, and selfestimation of competence in palliative care after elearning. BMC Med Educ. 2018;18(1):1-7. 
14. Wong KH, Allen A, Durrani TS. Evaluating Effectiveness of Online Learning Modules in Pediatric Environmental Health Education. J Med Toxicol. 2020 Dec 23;16(3):269-75.

15. Vavasseur A, Muscari F, Meyrignac O, Nodot M, Dedouit F, Revel-Mouroz P, et al. Blended learning of radiology improves medical students' performance, satisfaction, and engagement. Insights Imaging. 2020;11(1).

16. Browne CJ. Assessing the engagement rates and satisfaction levels of various clinical health science student sub-groups using supplementary eLearning resources in an introductory anatomy and physiology unit. Health Educ. 2019;119(1):2-17.

17. Petrie K, Trollor J, Dean K, Harvey S. Medical students' preferences regarding Psychiatry teaching: a comparison of different lecture delivery methods. MedEdPublish. 2019 Sep 6;8(3).

18. Reid HJ, Thomson C, McGlade KJ. Content and discontent: A qualitative exploration of obstacles to elearning engagement in medical students. BMC Med Educ [Internet]. 2016 Jul 22 [cited 2020 Apr 17];16(1):188. Available from: http://bmcmededuc.biomedcentral.com/articles/10.1186/s12909-016-0710-5

19. Maudsley G, Taylor D, Allam O, Garner J, Calinici T, Linkman K. A Best Evidence Medical Education (BEME) systematic review of: What works best for health professions students using mobile (hand-held) devices for educational support on clinical placements? BEME Guide No. 52. Med Teach [Internet]. 2019;41(2):125-40. Available from: https://doi.org/10.1080/0142159X.2018.1508829

20. Reames BN, Sheetz KH, Englesbe MJ, Waits SA. Evaluating the Use of Twitter to Enhance the Educational Experience of a Medical School Surgery Clerkship. J Surg Educ. 2016;73(1):73-8.

21. Coleman E, O'Connor E. The role of WhatsApp ${ }^{\circledR}$ in medical education; A scoping review and instructional design model. BMC Med Educ. 2019;19(1).

22. Masters K, Ellaway RH, Topps D, Archibald D, Hogue RJ. Mobile technologies in medical education: AMEE Guide No. 105. Med Teach. 2016 Jun 2;38(6):537-49.

23. Ellaway R. E-learning: Is the revolution over? Med Teach. 2011;33(4):297-302.

24. Quant C, Altieri L, Torres J, Craft N. The Self-Perception and Usage of Medical Apps amongst Medical Students in the United States: A Cross-Sectional Survey. Int J Telemed Appl. 2016;2016:3929741.

25. Tran K, Morra D, Lo V, Quan SD, Abrams H, Wu RC. Medical students and personal smartphones in the clinical environment: the impact on confidentiality of personal health information and professionalism. J Med Internet Res. 2014 May;16(5):e132.

26. Rashid-Doubell F, Mohamed S, Elmusharaf K, O'Neill CS. A balancing act: a phenomenological exploration of medical students' experiences of using mobile devices in the clinical setting. BMJ Open. 2016 May;6(5):e011896.

27. Witt RE, Kebaetse MB, Holmes JH, Littman-Quinn R, Ketshogileng D, Antwi C, et al. The role of tablets in accessing information throughout undergraduate medical education in Botswana. Int J Med Inform. 2016 Apr;88:71-7.

28. Johansson PE, Petersson GI, Nilsson GC. Nursing students' experience of using a personal digital assistant (PDA) in clinical practice - an intervention study. Nurse Educ Today. 2013 Oct;33(10):1246-51.

29. Green BL, Kennedy I, Hassanzadeh H, Sharma S, Frith G, Darling JC. A semi-quantitative and thematic analysis of medical student attitudes towards MLearning. J Eval Clin Pract. 2015 Oct;21(5):925-30.

30. Davies BS, Rafique J, Vincent TR, Fairclough J, Packer MH, Vincent R, et al. Mobile Medical Education (MoMEd) - how mobile information resources contribute to learning for undergraduate clinical students - a mixed methods study. BMC Med Educ. 2012 Jan;12:1.

31. Brandenburg DC, Ellinger AD. The Future: Just-in-Time Learning Expectations and Potential Implications for Human Resource Development. Adv Dev Hum Resour. 2003 Aug;5(3):308-20.

32. Masters K, Ellaway RH, Topps D, Archibald D, Hogue RJ. Mobile technologies in medical education: AMEE Guide No. 105. Med Teach. 2016;38(6):53749.

33. Fiji National Debt 2018 | countryeconomy.com [Internet]. [cited 2020 Sep 3]. p. undefined-undefined. Available from: https://countryeconomy.com/national-debt/fiji

34. The World Bank. Jordan | Data [Internet]. 2016 [cited 2020 Sep 3]. Available from: https://data.worldbank.org/country/jordan

35. Childs S, Blenkinsopp E, Hall A, Walton G. Effective e-learning for health professionals and students-barriers and their solutions. A systematic review of the literature--findings from the HeXL project. [Internet]. Vol. 22 Suppl 2, Health information and libraries journal. 2005 [cited 2020 Mar 30 ]. Available from: http://www.institute.nhs.uk/

\section{Tables}




\begin{tabular}{|ll|}
\hline Mean & 3.3488 \\
\hline Median & 3.4000 \\
Mode & 3.00 \\
\hline Std. Deviation & 0.48128 \\
\hline Range & 2.00 \\
Minimum & 2.00 \\
\hline Maximum & 4.00 \\
\hline
\end{tabular}

Table 1: Statistical analysis of basic science and clinical medical students' GPA.

\begin{tabular}{|c|c|c|c|c|c|c|}
\hline & & \multicolumn{3}{|c|}{ Student Satisfaction (All) } & \multirow[t]{2}{*}{ Total } & \multirow[t]{2}{*}{ P-value } \\
\hline & & Unsatisfied & Neutral & Satisfied & & \\
\hline \multirow[t]{2}{*}{ Gender } & Male & $148(38.0 \%)$ & $170(43.7 \%)$ & $71(18.3 \%)$ & $389(100.0 \%)$ & \multirow[t]{2}{*}{0.394} \\
\hline & Female & $197(32.2 \%)$ & $294(48.1 \%)$ & $120(19.6 \%)$ & $611(100.0 \%)$ & \\
\hline Total & & $345(34.5 \%)$ & $464(46.4 \%)$ & $191(19.1 \%)$ & $1000(100.0 \%)$ & \\
\hline \multirow[t]{2}{*}{ Academic Level } & Basic & $156(30.8 \%)$ & $245(48.4 \%)$ & $105(20.8 \%)$ & $506(100.0 \%)$ & \multirow[t]{2}{*}{0.012} \\
\hline & Clinical & $189(38.3 \%)$ & $219(44.3 \%)$ & $86(17.4 \%)$ & $494(100.0 \%)$ & \\
\hline Total & & $345(34.5 \%)$ & $464(46.4 \%)$ & $191(19.1 \%)$ & $1000(100.0 \%)$ & \\
\hline \multirow[t]{3}{*}{ GPA Level } & $\mathrm{C}$ & $29(42.6 \%)$ & $27(39.7 \%)$ & $12(17.6 \%)$ & $68(100.0 \%)$ & \multirow[t]{3}{*}{0.501} \\
\hline & $\mathrm{B}$ & $109(32.6 \%)$ & $162(48.5 \%)$ & $63(18.9 \%)$ & $334(100.0 \%)$ & \\
\hline & A & $54(35.8 \%)$ & $66(43.7 \%)$ & $31(20.5 \%)$ & $151(100.0 \%)$ & \\
\hline Total & & $192(34.7 \%)$ & $255(46.1 \%)$ & $106(19.2 \%)$ & $553(100.0 \%)$ & \\
\hline \multirow[t]{2}{*}{ Student Preparedness Level } & Non experienced & $222(42.9 \%)$ & $237(45.8 \%)$ & $58(11.2 \%)$ & $517(100.0 \%)$ & \multirow[t]{2}{*}{0.000} \\
\hline & Experienced & $123(25.5 \%)$ & $227(47.0 \%)$ & $133(27.5 \%)$ & $483(100.0 \%)$ & \\
\hline Total & & $345(34.5 \%)$ & $464(46.4 \%)$ & $191(19.1 \%)$ & $1000(100.0 \%)$ & \\
\hline \multirow[t]{3}{*}{ Teacher e-learning performance } & Unsatisfying & $144(68.6 \%)$ & $56(26.7 \%)$ & $10(4.8 \%)$ & $210(100.0 \%)$ & \multirow[t]{3}{*}{0.000} \\
\hline & Neutral & $148(31.0 \%)$ & $271(56.8 \%)$ & $58(12.2 \%)$ & $477(100.0 \%)$ & \\
\hline & Satisfying & $53(16.9 \%)$ & $137(43.8 \%)$ & $123(39.3 \%)$ & $313(100.0 \%)$ & \\
\hline Total & & $345(34.5 \%)$ & $464(46.4 \%)$ & $191(19.1 \%)$ & $1000(100.0 \%)$ & \\
\hline \multirow[t]{3}{*}{ Beck Anxiety Inventory } & Low & $253(33.2 \%)$ & $351(46.0 \%)$ & $159(20.8 \%)$ & $763(100.0 \%)$ & \multirow[t]{3}{*}{0.455} \\
\hline & Moderate & 55 (34.8\%) & $79(50.0 \%)$ & $24(15.2 \%)$ & $158(100.0 \%)$ & \\
\hline & Severe & 37 (46.8\%) & $34(43.0 \%)$ & $8(10.1 \%)$ & 79 (100.0\%) & \\
\hline Total & & $345(34.5 \%)$ & $464(46.4 \%)$ & $191(19.1 \%)$ & $1000(100.0 \%)$ & \\
\hline \multirow[t]{5}{*}{ UJ e-Learning website is easily accessible } & Strongly disagree & $42(58.3 \%)$ & $25(34.7 \%)$ & $5(6.9 \%)$ & $72(100.0 \%)$ & \multirow[t]{5}{*}{0.000} \\
\hline & Disagree & $93(42.9 \%)$ & $93(42.9 \%)$ & $31(14.3 \%)$ & $217(100.0 \%)$ & \\
\hline & Neither agree nor disagree & $75(29.8 \%)$ & $128(50.8 \%)$ & 49 (19.4\%) & $252(100.0 \%)$ & \\
\hline & Agree & $122(30.8 \%)$ & $193(48.7 \%)$ & $81(20.5 \%)$ & $396(100.0 \%)$ & \\
\hline & Strongly agree & $13(21.0 \%)$ & $24(38.7 \%)$ & $25(40.3 \%)$ & $62(100.0 \%)$ & \\
\hline Total & & $345(34.5 \%)$ & $464(46.4 \%)$ & $191(19.1 \%)$ & $999(100.0 \%)$ & \\
\hline
\end{tabular}

Table 2: The relationship between the levels of student satisfaction and each of: gender, academic level, GPA, student preparedness, teacher e-learning performance and Beck Anxiety Inventory result. 


\begin{tabular}{|c|c|c|c|c|c|c|c|}
\hline & & \multicolumn{4}{|c|}{ Attainment of theoretical medical knowledge (among all basic and clinical students) } & \multirow[t]{2}{*}{ Total } & \multirow{2}{*}{$\begin{array}{l}\text { P- } \\
\text { value }\end{array}$} \\
\hline & & $\begin{array}{l}\text { I experience difficulty } \\
\text { in understanding }\end{array}$ & $\begin{array}{l}\text { I gain and } \\
\text { understand less }\end{array}$ & $\begin{array}{l}\text { I gain and } \\
\text { understand the } \\
\text { same }\end{array}$ & $\begin{array}{l}\text { I gain and } \\
\text { understand } \\
\text { better }\end{array}$ & & \\
\hline \multirow[t]{2}{*}{ Gender } & Male & $32(8.2 \%)$ & $125(32.1 \%)$ & $138(35.5 \%)$ & $94(24.2 \%)$ & $\begin{array}{l}389 \\
(100.0 \%)\end{array}$ & \multirow[t]{2}{*}{0.478} \\
\hline & Female & $34(5.6 \%)$ & $193(31.6 \%)$ & $241(39.4 \%)$ & $143(23.4 \%)$ & $\begin{array}{l}611 \\
(100.0 \%)\end{array}$ & \\
\hline Total & & $66(6.6 \%)$ & $318(31.8 \%)$ & $379(37.9 \%)$ & $237(23.7 \%)$ & $\begin{array}{l}1000 \\
(100.0 \%)\end{array}$ & \\
\hline \multirow[t]{2}{*}{ Academic Level } & Basic & $35(6.9 \%)$ & $149(29.4 \%)$ & $202(39.9 \%)$ & $120(23.7 \%)$ & $\begin{array}{l}506 \\
(100.0 \%)\end{array}$ & \multirow[t]{2}{*}{0.281} \\
\hline & Clinical & 31 (6.3\%) & $169(34.2 \%)$ & 177 (35.8\%) & $117(23.7 \%)$ & $\begin{array}{l}494 \\
(100.0 \%)\end{array}$ & \\
\hline Total & & 66 (6.6\%) & 318 (31.8\%) & 379 (37.9\%) & 237 (23.7\%) & $\begin{array}{l}1000 \\
(100.0 \%)\end{array}$ & \\
\hline \multirow[t]{3}{*}{ GPA Level } & $\mathrm{C}$ & $5(7.4 \%)$ & $28(41.2 \%)$ & $20(29.4 \%)$ & 15 (22.1\%) & $\begin{array}{l}68 \\
(100.0 \%)\end{array}$ & \multirow[t]{3}{*}{0.398} \\
\hline & B & $20(6.0 \%)$ & $108(32.3 \%)$ & $118(35.3 \%)$ & 88 (26.3\%) & $\begin{array}{l}334 \\
(100.0 \%)\end{array}$ & \\
\hline & $A$ & $10(6.6 \%)$ & $44(29.1 \%)$ & $66(43.7 \%)$ & 31 (20.5\%) & $\begin{array}{l}151 \\
(100.0 \%)\end{array}$ & \\
\hline Total & & 35 (6.3\%) & $180(32.5 \%)$ & $204(36.9 \%)$ & $134(24.2 \%)$ & $\begin{array}{l}553 \\
(100.0 \%)\end{array}$ & \\
\hline \multirow[t]{3}{*}{$\begin{array}{l}\text { Teacher e-learning } \\
\text { performance }\end{array}$} & Unsatisfying & 45 (21.4\%) & $102(48.6 \%)$ & $45(21.4 \%)$ & $18(8.6 \%)$ & $\begin{array}{l}210 \\
(100.0 \%)\end{array}$ & \multirow[t]{3}{*}{0.000} \\
\hline & Neutral & $19(4.0 \%)$ & $162(34.0 \%)$ & $198(41.5 \%)$ & 98 (20.5\%) & $\begin{array}{l}477 \\
(100.0 \%)\end{array}$ & \\
\hline & Satisfying & $2(0.6 \%)$ & $54(17.3 \%)$ & $136(43.5 \%)$ & $121(38.7 \%)$ & $\begin{array}{l}313 \\
(100.0 \%)\end{array}$ & \\
\hline Total & & $66(6.6 \%)$ & 318 (31.8\%) & 379 (37.9\%) & $237(23.7 \%)$ & $\begin{array}{l}1000 \\
(100.0 \%)\end{array}$ & \\
\hline \multirow[t]{5}{*}{$\begin{array}{l}\text { UJ e-Learning website is } \\
\text { easily accessible }\end{array}$} & $\begin{array}{l}\text { Strongly } \\
\text { disagree }\end{array}$ & $18(25.0 \%)$ & 19 (26.4\%) & $21(29.2 \%)$ & $14(19.4 \%)$ & $\begin{array}{l}72 \\
(100.0 \%)\end{array}$ & \multirow[t]{5}{*}{0.001} \\
\hline & Disagree & $14(6.5 \%)$ & $76(35.0 \%)$ & $81(37.3 \%)$ & $46(21.2 \%)$ & $\begin{array}{l}217 \\
(100.0 \%)\end{array}$ & \\
\hline & $\begin{array}{l}\text { Neither agree } \\
\text { nor disagree }\end{array}$ & $21(8.3 \%)$ & 77 (30.6\%) & $96(38.1 \%)$ & $58(23.0 \%)$ & $\begin{array}{l}252 \\
(100.0 \%)\end{array}$ & \\
\hline & Agree & $12(3.0 \%)$ & $130(32.8 \%)$ & $163(41.2 \%)$ & $91(23.0 \%)$ & $\begin{array}{l}396 \\
(100.0 \%)\end{array}$ & \\
\hline & Strongly agree & $1(1.6 \%)$ & $16(25.8 \%)$ & $17(27.4 \%)$ & 28 (45.2\%) & $\begin{array}{l}62 \\
(100.0 \%)\end{array}$ & \\
\hline Total & & $66(6.6 \%)$ & $318(31.8 \%)$ & $378(37.8 \%)$ & 237 (23.7\%) & $\begin{array}{l}999 \\
(100.0 \%)\end{array}$ & \\
\hline
\end{tabular}

Table 3: The relationship between level of attainment of medical knowledge for all medical students and each of: gender, academic level, GPA, teacher elearning performance and Beck Anxiety Inventory result. 
Attainment of clinical medical knowledge (among clinical students only)

I experience difficulty in I gain and understanding

Gender

Total

GPA Level

B

B $\quad 51(24.5 \%)$

A

Male

$63(29.2 \%)$

Female

$68(24.5 \%)$

$131(26.5 \%)$

C $\quad 10(22.7 \%)$

$13(30.2 \%)$

$74(25.1 \%)$

Total

Teacher e-Learning

performance

74

I gain and
understand less

I gain and
understand the
same

$98(45.4 \%) \quad 40(18.5 \%)$

$159(57.2 \%) \quad 35(12.6 \%)$

Unsatisfying $\quad 43(47.8 \%)$

$68(29.3 \%)$

Neutral

$(28$

Satisfying 20

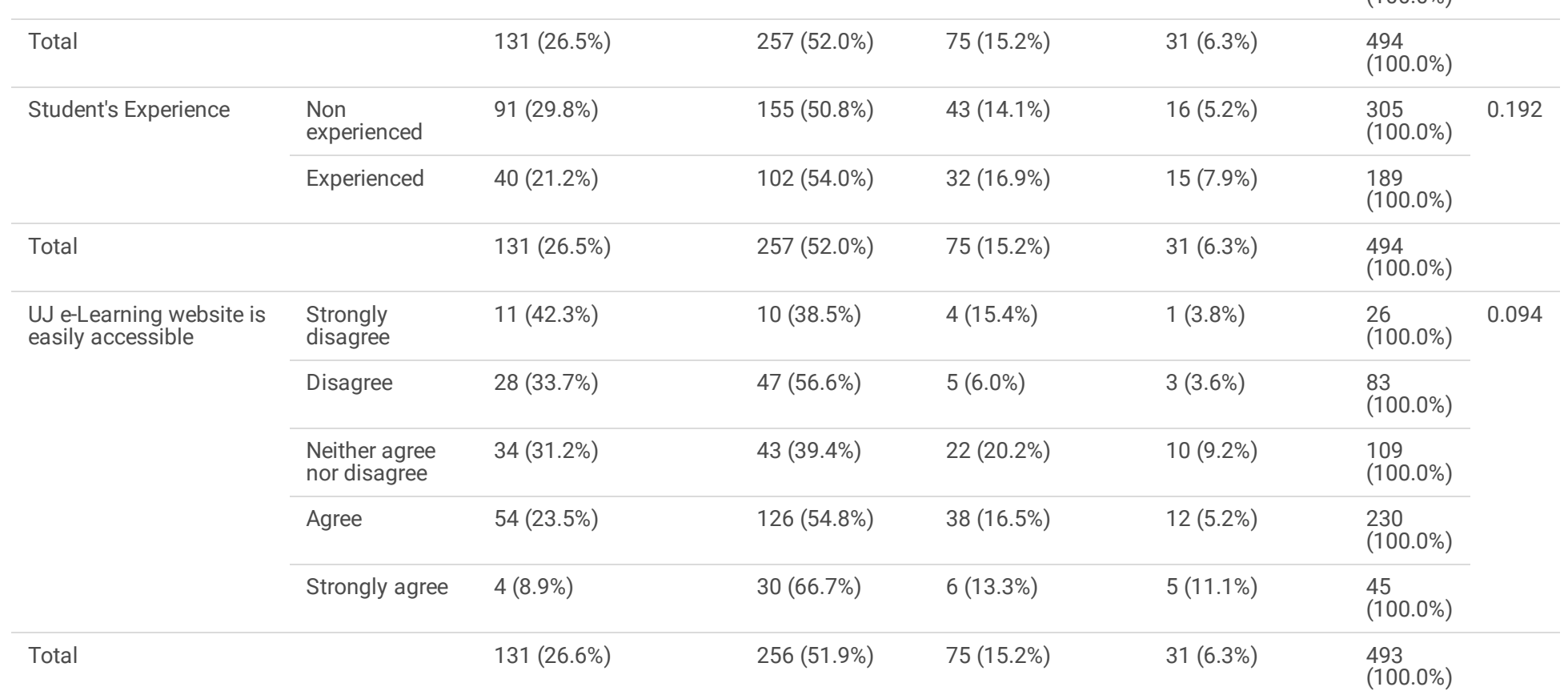

Table 4: The relationship between level of attainment of medical knowledge for clinical students and each of: gender, academic level, GPA, teacher e-learning performance and Beck Anxiety Inventory result. 


\begin{tabular}{ll} 
Most beneficial tool & $\%$ \\
\hline Moodle & 48.5 \\
\hline WhatsApp & 28.2 \\
\hline Facebook & 29.1 \\
\hline Microsoft Teams & 24.0 \\
\hline Zoom/Skype & 60 \\
\hline YouTube & 56.7
\end{tabular}

Table 5: The most common platforms used in e-learning in this study.

\section{Figures}

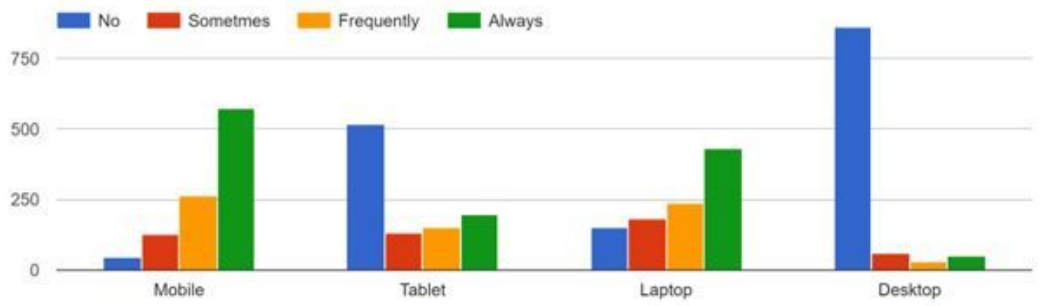

\section{Figure 1}

The most common devices used to connect to the internet 